Ergul Mutlu Altundag*, Duygu Gençalp, Cahit Özbilenler, Kübra Toprak and Namık Kerküklü

\title{
In vitro antioxidant, anti-inflammatory and anti-cancer activities of methanolic extract of Asparagus horridus grows in North Cyprus Kuzey Kıbrıs da yetişen Asparagus horridus metanolik ekstraktının in-vitro antioksidan, anti-enflamatuar ve anti-kanser aktivitesi
}

https://doi.org/10.1515/tjb-2019-0325

Received July 30, 2019; accepted December 25, 2019

\section{Abstract}

Background: Asparagus horridus is an edible plant known as "Ayrelli" in North Cyprus. The scientific literature has not yet submitted a report about the antioxidant, anti-inflammatory and anti-cancer activities of $A$. horridus plant from North Cyprus until now. The purpose of the research was to determine the antioxidant, anti-inflammatory and anti-cancer activities of $A$. horridus.

Materials and methods: Soxhlet extraction of $A$. horridus was performed using methanol. Antioxidant activity was determined by DPPH, TFC, FRAP and TPC assays. Proteindenaturation assay was performed to determine the antiinflammatory effect. The anti-cancer effects of the extract on HepG2 and B-CPAP cell lines were determined with MTT assay.

*Corresponding author: Ergul Mutlu Altundag, Eastern Mediterranean University, Faculty of Medicine, Medical Biochemistry, North Cyprus via Mersin 10, Famagusta 99628, North Cyprus, Turkey, e-mail: ergulmutlu81@gmail.com. https://orcid.org/0000-00022377-4047

Duygu Gençalp: Eastern Mediterranean University, Faculty of Medicine, Medical Biochemistry, Famagusta, North Cyprus, Turkey Cahit Özbilenler and Namık Kerküklü: Eastern Mediterranean University, Faculty of Art and Sciences, Chemistry, Famagusta, North Cyprus, Turkey

Kübra Toprak: Marmara Universitesi, Genetic and Metabolic Diseases Research Center, Istanbul, Turkey
Results: Antioxidant activity for A. horridus extract was determined by DPPH (50\%), TFC (266.26 $\mu \mathrm{g}$ QUE/mg extract), FRAP (1.27 $\mu \mathrm{g} \mathrm{FeSO} / \mathrm{mg}$ extract) and TPC $(167.613 \mu \mathrm{g}$ GAE $/ \mathrm{mg}$ extract) assays at $25 \mathrm{mg} / \mathrm{mL}$. Inhibition of protein-denaturation activity was found as $29.42 \%$ at $25 \mathrm{mg} / \mathrm{mL}$. After $24 \mathrm{~h}$ of the extract treatment, cell proliferation of HepG2 and B-CPAP cancer cells were inhibited at $\mathrm{IC}_{50}$ values $63.24 \mu \mathrm{g} / \mathrm{mL}$ and $101.24 \mu \mathrm{g} / \mathrm{mL}$, respectively.

Conclusion: These results have shown that the methanol extract of $A$. horridus grows in North Cyprus has antioxidant, anti-inflammatory and anti-cancer activities.

Keywords: Asparagus horridus; North Cyprus; Antioxidant; Anti-inflammatory; Anti-cancer.

\section{öz}

Amaç: Asparagus horridus Kuzey Kıbrıs' ta "Ayrelli" olarak bilinen yenilebilir bir bitkidir. Bilimsel literatürde Kuzey Kıbrıs'ta yetişen $A$. horridus bitkisinin antioksidan, anti-enflamatuar ve antikanser aktiviteleri ile ilgili şu ana kadar bir rapor yayınlanmamıştır. Araştırmanın amacı, $A$. horridus' un antioksidan, anti-enflamatuar ve antikanser etkilerini belirlemektir.

Gereç ve Yöntem: Asparagus horridus özütünü elde etmek için Soxhlet ekstraksiyon metodu methanol kullanılarak gerçekleştirildi. Antioksidan aktivitesi DPPH, TFC, FRAP ve TPC testleri ile belirlenmiştir. Ekstraktın anti-enflamatuar etkisini belirlemek için protein-denatürasyon analizi yapıldı. Ekstraktın HepG2 ve B-CPAP hücreleri üzerindeki antikanser etkileri ise MTT testi ile belirlendi. 
Bulgular: Asparagus horridus ekstraktının antioksidan aktivitesi, DPPH (50\%), TFC (266.26 $\mu \mathrm{g}$ QUE/mg ekstrakt), FRAP $\left(1.27 \mu \mathrm{g} \mathrm{FeSO}_{4} / \mathrm{mg}\right.$ ekstrakt) ve TPC (167.613 $\mu \mathrm{g}$ GAE/ mg ekstrakt) analizlerinden $25 \mathrm{mg} / \mathrm{mL}$ ' de elde edilen sonuçlara göre belirlendi. Protein denatürasyonu aktivitesinin inhibisyonu, $25 \mathrm{mg} / \mathrm{mL}$ ' de $29.42 \%$ olarak bulundu. 24 saat ekstrakt muamelesinden sonra, HepG2 ve B-CPAP kanser hücrelerinin hücre proliferasyonu, sirasıyla $\mathrm{IC}_{50}$ değerlerinde $63.24 \mu \mathrm{g} / \mathrm{mL}$ ve $101.24 \mu \mathrm{g} / \mathrm{mL}$ önemli ölçüde inhibe edildi.

Sonuç: Bu sonuçlar, Kuzey Kıbrıs' da yetişen A. horridus' un metanol ekstraktının önemli antioksidan, antienflamatuar ve anti-kanser aktiviteye sahip olduğunu göstermiştir.

Anahtar kelimeler: Asparagus horridus; Kuzey Kıbrıs; Antioksidan; Anti-enflamatuar; Anti-kanser.

\section{Introduction}

In recent years, interest in studies involving medicinal plants has increased considerably. Edible plants such as Asparagus have been used in Chinese and Indian medicine as a diuretic, in cancer treatments, remedies for neuritis and rheumatism, to relieve toothache, antitussive and antifebrile [1, 2]. Asparagus is a genus (Liliaceae family) that includes 300 species and known to be grown mostly in Mediterranean, Eastern Asia and some parts of Africa [3-5].

Different studies on Asparagus species have demonstrated anti-cancer (including breast cancer [6], leukemia [6], lung cancer [6] and liver cancer [7]), anti-inflammatory and antioxidant activities [8-10]. It has been reported that a methanolic extract of different types of Asparagus has a strong antioxidant capacity [11]. Asparagus horridus, an edible plant known as "Ayrelli", is a common type of Asparagus in North Cyprus. The scientific literature has not yet submitted a report about the antioxidant and anti-cancer activities of $A$. horridus plant from North Cyprus until now. Besides that, there has been no pharmacological study performed specifically on $A$. horridus in literature.

The main purpose of this study is to evaluate the antioxidant, anti-inflammatory and anti-cancer activity of $A$. horridus methanolic extract. The present study is the first study to evaluate the potential anti-proliferative activity of $A$. horridus on both HepG2 and B-CPAP cells. In conclusion, significant anticancer activity against both liver and thyroid cancer cells of $A$. horridus methanolic extract indicates that it is a potential therapeutic agent for cancer therapy.

\section{Materials and methods}

\section{Chemicals and reagents}

Methanol (CN: 24229) used for the soxhlet extraction of asparagus samples was obtained from Sigma-Aldrich (St. Louis, MO, USA). For the antioxidant assay, 1,1-diphenyl-2-picrylhydrazyl (DPPH) (CN: D9132), dimethyl sulfoxide (DMSO) (CN: 472301) and gallic acid (CN: 398225) were purchased from Sigma-Aldrich (St. Louis, MO, USA). Aluminum chloride (Product code: 10558030) was purchased from Fisher-Scientific and quercetin (CN: Q4951) was obtained from Sigma-Aldrich (St. Louis, MO, USA) for use in total flavonoid content determination. Folin reagent (CN: F9252) and sodium carbonate (CN: 13418) used in total phenolic content determination experiments were also purchased from Sigma-Aldrich (St. Louis, MO, USA). In the use of ferric reducing antioxidant power assay, potassium ferricyanide (CN: 244023), trichloroacetic acid (CN: T6399), iron sulfate (CN: F1543) and iron(III) chloride (CN: 8039451000) were obtained from Sigma-Aldrich (St. Louis, MO, USA). Protein denaturation assay was done with the use of bovine serum albumin (BSA) (CN: 232936-2) obtained from SigmaAldrich (St. Louis, MO, USA). Diclofenac Sodium (ATC code: M01AB05) purchased from Deva (Kucukcekmece, İstanbul, Turkey) in the form of ampoules.

\section{Plant collection}

Plant samples were collected from Famagusta North

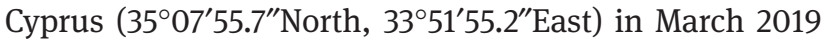
and identified as A. horridus by Prof. Dr. F. Neriman Özhatay, Herbarium Botanist, Faculty of Pharmacy, Eastern Mediterranean University (EMU). A herbarium specimen (voucher number: DE 001) has been deposited and retained in the above herbarium. Plant name was checked with http://www.theplantlist.org.

\section{Methanolic extract preparation}

The plant material was washed with distilled water, air-dried at room temperature and grounded to powder form. Soxhlet extraction was used to obtain the extract from $10 \mathrm{~g} \mathrm{~A}$. horridus plant powder using $300 \mathrm{~mL}$ methanol. The extraction process was repeated three times at $70^{\circ} \mathrm{C}$ in which each cycle lasted $8 \mathrm{~h}$. The extract was filtered and the solvent was completely removed using a rotary evaporator. 


\section{Antioxidant assays}

\section{1,1-Diphenyl-2-picrylhydrazyl (DPPH) assay}

The antioxidant activities of the methanolic extract of A. horridus was determined using a method based on the reduction of DPPH by Alara et al. [12] with modifications. The extract was dissolved in DMSO and then $5 \mu \mathrm{L}$ of different doses from each extract was mixed with $195 \mu \mathrm{L}$ DPPH. The mixture was left in a dark room for $30 \mathrm{~min}$ at room temperature. At the end of the incubation, absorbance was measured at $517 \mathrm{~nm}$ using a 96-well plate with Varioskan Flash Multimode Microplate Reader (Thermo-FisherScientific, Waltham, MA, USA) and gallic acid was used as a standard with the doses ranging from 0 to $200 \mu \mathrm{g} /$ $\mathrm{mL}$. The inhibition percentages of the radical scavenging activity were calculated with the following formula, which "control" shows the absorbance of methanol mixed with DPPH solution and a "sample" shows the absorbance of A. horridus extract mixed with DPPH solution.

$\%$ Inhibition $=\left[\left(\mathrm{Abs}_{\text {control }}-\mathrm{Abs}_{\text {sample }}\right) / \mathrm{Abs}_{\text {control }}\right] \times 100$

\section{Total flavonoid content (TFC)}

TFC of the extract was measured using the aluminum chloride $\left(\mathrm{AlCl}_{3}\right)$ colorimetric method described by Kim et al. [13] with minor modifications. Extract solution with a volume of $50 \mu \mathrm{L}$ was mixed with $50 \mu \mathrm{L}$ of $2 \% \mathrm{AlCl}_{3}$ solution and incubated for $1 \mathrm{~h}$ at room temperature. The absorbance of the supernatant was measured at $420 \mathrm{~nm}$ via Varioskan Flash Multimode Microplate Reader (Thermo-Fisher-Scientific, Waltham, MA, USA). Quercetin was used as a standard to draw the calibration curve $\left(y=0.0058 x+0.0351 ; r^{2}=0.98811\right)$. The concentration of flavonoid was expressed as $\mu$ g quercetin equivalent (QE) per mg extract ( $\mu \mathrm{g} \mathrm{QE} / \mathrm{mg}$ extract).

\section{Total phenolic content (TPC)}

Total phenolic content of the A. horridus extract was measured using Folin-Ciocalteu reagent method with minor modifications $[12,14]$. After the transfer of $50 \mu \mathrm{L}$ from each extract concentration into well plates, $100 \mu \mathrm{L}$ folin reagent and $100 \mu \mathrm{L}$ of sodium carbonate $\left(\mathrm{Na}_{2} \mathrm{CO}_{3}\right)$ solution was added sequentially to each reaction mixture and then incubated for $30 \mathrm{~min}$ at $25^{\circ} \mathrm{C}$ prior to absorbance measurements at $765 \mathrm{~nm}$ using a Varioskan Flash Multimode Microplate Reader (Thermo-Fisher-Scientific,
Waltham, MA, USA). Gallic acid $(0-250 \mu \mathrm{g} / \mathrm{mL})$ was used as a standard to draw the calibration curve $\left(y=0.0058 x-0.1034 ; r^{2}=0.99174\right)$. The results expressed as $\mu \mathrm{g}$ gallic acid equivalent (GAE) per mg of extract ( $\mu \mathrm{g}$ $\mathrm{GAE} / \mathrm{mg}$ extract).

\section{Ferric reducing antioxidant power (FRAP assay)}

The FRAP assay was performed using the Vijayalakshmi and Ruckmani methods with slight modifications [15]. Twenty microliter from the different concentrations of plant extract $(1-25 \mathrm{mg} / \mathrm{mL})$ was added to $50 \mu \mathrm{L}$ phosphate buffer $(0.2 \mathrm{M}, \mathrm{pH}=6.6)$ and $50 \mu \mathrm{L} 1 \%$ potassium ferricyanide $\left[\mathrm{K}_{3} \mathrm{Fe}(\mathrm{CN})_{6}\right]$ solution. Mixture was vortexed and incubated at $50^{\circ} \mathrm{C}$ for $20 \mathrm{~min}$ in a water bath. After the incubation, $50 \mu \mathrm{L} \mathrm{10 \%} \mathrm{trichloroacetic} \mathrm{acid} \mathrm{(TCA)} \mathrm{was}$ added to the reaction mixture and centrifuged for $10 \mathrm{~min}$ at $704 \mathrm{~g}$. At the end of the centrifugation, $200 \mu \mathrm{L}$ of the supernatant was mixed with the same proportion of distilled water and $40 \mu \mathrm{L}$ of $0.1 \%$ ferric chloride. Absorbance was measured at $700 \mathrm{~nm}$ using a Varioskan Flash Multimode Microplate Reader (Thermo-Fisher-Scientific, Waltham, MA, USA). Different concentrations (100-300 $\mu \mathrm{g} / \mathrm{mL}$ ) of ferrous sulfate $\left(\mathrm{FeSO}_{4}\right)$ was used as a standard to draw the calibration curve $(y=0.0003 x-0.0707$; $\left.r^{2}=0.89526\right)$.

\section{Protein-denaturation assay}

Protein denaturation assay was performed based on procedure described by Williams et al. [16]. While preparing the reaction mixture, different concentrations $(1-25 \mathrm{mg} / \mathrm{mL})$ of $A$. horridus extract were mixed with $0.5 \mathrm{~mL}$ of $1.5 \mathrm{mg} / \mathrm{mL}$ BSA and incubated at $37^{\circ} \mathrm{C}$ for $20 \mathrm{~min}$. Thereafter, reaction mixtures were heated for $3 \mathrm{~min}$ at $57^{\circ} \mathrm{C}$ and $0.5 \mathrm{M}$ phosphate buffer $(\mathrm{pH}=6.3)$ with a volume of $250 \mu \mathrm{L}$ was added to each reaction mixture and mixed thoroughly. Subsequently after even distribution of molecules in each reaction mixture, $100 \mu \mathrm{L}$ from each mixture was transferred into separate test tubes followed by the addition of copper-alkaline reagent and $1 \%$ (v/v) Folin-Ciocalteu's reagent with the same proportion by volume. Following to the $10 \mathrm{~min}$ incubation at $55^{\circ} \mathrm{C}$, the tubes were allowed to cool down and absorbance was measured at $650 \mathrm{~nm}$ using a Varioskan Flash Multimode Microplate Reader (Thermo-Fisher-Scientific, Waltham, MA, USA). Recorded measurements were evaluated by using different concentrations of diclofenac sodium $(100-1000 \mu \mathrm{g} / \mathrm{mL})$ as a reference drug. 


\section{Cell culture and cell viability}

Cell culture experiment was performed on both human liver cancer cell line HepG2 (ATCC, HB-8065) obtained from ATCC (Manassas, VA, USA) and papillary thyroid carcinoma cell line B-CPAP (DSMZ, ACC 27) obtained from German Collection of Microorganisms and Cell Cultures (Braunschweig, Germany). Cells were cultured in Roswell Park Memorial Institute 1640 Medium (RPMI-1640) (Biochrom, Berlin, Germany) supplemented with $10 \%$ fetal bovine serum (FBS; Hyclone Laboratories, Logan, UT, USA), $1 \%$ L-glutamine, $1 \%$ penicillin-streptomycin in a $5 \% \mathrm{CO}_{2}$ incubator at $37^{\circ} \mathrm{C}$. Cell viability was determined using the MTT (3-(4,5-dimethylthiazol-2-yl)-2,5-diphenyl tetrazolium bromide) (Sigma, M2003) assay described by Heijden et al. [17]. MTT is a quantitative colorimetric assay for measuring cellular growth, cell survival and cell proliferation based on the quantity of living cells. Asparagus horridus extract stock solution $(200 \mathrm{mg} / \mathrm{mL})$ was prepared in DMSO and stored at $-20^{\circ} \mathrm{C}$. Before being used in MTT assay, the stock solution was diluted with RPMI1640 medium to keep final concentration of DMSO below $0.1 \%$ in extract solution. For MTT assay, $10 \times 10^{3}$ cells/well were seeded in 96 well plates in $100 \mu \mathrm{L}$ of medium and incubated at $37^{\circ} \mathrm{C}$ for $24 \mathrm{~h}$. Cells were then treated with different concentrations of $A$. horridus extract and incubated for $24 \mathrm{~h}$. Afterward, $10 \mu \mathrm{L}$ of $5 \mathrm{mg} / \mathrm{mL}$ solution of MTT in PBS was added to each well plates. After $4 \mathrm{~h}$ of incubation with MTT at $37^{\circ} \mathrm{C}$, supernatant was carefully removed and then $100 \mu \mathrm{L}$ DMSO was added to each well. Plates were then placed in a microplate shaker for $5 \mathrm{~min}$. Finally, cell viability assay was determined by measuring the absorbance at $595 \mathrm{~nm}$ with a Varioskan Flash Multimode Microplate Reader (Thermo-Fisher-Scientific, Waltham, MA, USA). The percentage of cell viability was calculated manually using the formula:

$\%$ Viable cells $=$

$$
\left(\mathrm{Abs}_{\text {sample }}-\mathrm{Abs}_{\text {blank }}\right) /\left(\mathrm{Abs}_{\text {control }}-\mathrm{Abs}_{\text {blank }}\right) \star 100
$$

The mean of triplicate experiments for each dose was used to calculate the concentration of extract required for $50 \%$ inhibition of cell viability $\left(\mathrm{IC}_{50}\right.$ ) as determined using the Biosoft CalcuSyn program.

\section{Statistical analysis}

The experiments were performed in triplicates and results were expressed as mean \pm standard deviation (SD). Test results were calculated in Microsoft Excel
2015 software (Microsoft, Redmond, WA, USA). For statistical comparisons, results were analyzed using ANOVA/ Dunnet's Multiple Comparisons test and GraphPad Prism Version 8 software to carry out statistical tests. A statistical significance of $\mathrm{p}<0.05$ was considered as significant.

\section{Results}

\section{Determination of antioxidant activities}

The DPPH assay was used to determine the antioxidant potential of plant extracts by measuring their ability to act as free radical scavengers. Evaluation of antioxidant activities for standard gallic acid concentrations at 10 and $200 \mu \mathrm{g} / \mathrm{mL}$ indicated $9.37 \%$ and $60.92 \%$, respectively (data was not shown). Increase in A. horridus extract concentration resulted in a simultaneous increase in DPPH radical scavenging activities significantly at extract concentration of $10 \mathrm{mg} / \mathrm{mL}(\mathrm{p}<0.05)$ and $15,20,25 \mathrm{mg} / \mathrm{mL}(\mathrm{p}<0.0001)$ compared to $1 \mathrm{mg} / \mathrm{mL}$ concentration of extract. No difference (ns\#) was observed between $1 \mathrm{mg} / \mathrm{mL}(4 \%)$ and $5 \mathrm{mg} / \mathrm{mL}(4 \%)$ concentration of extract. The highest DPPH scavenging activity of methanolic extract of $A$. horridus was $50 \%$ at $25 \mathrm{mg} / \mathrm{mL}$ (Figure 1).

Total flavonoid content (TFC) of extract was measured via colorimetric method using aluminium chloride. The results were derived from the calibration curve $\left(y=0.0058 x+0.0351 ; r^{2}=0.98811\right)$ of quercetin $(0-200 \mu \mathrm{g} /$

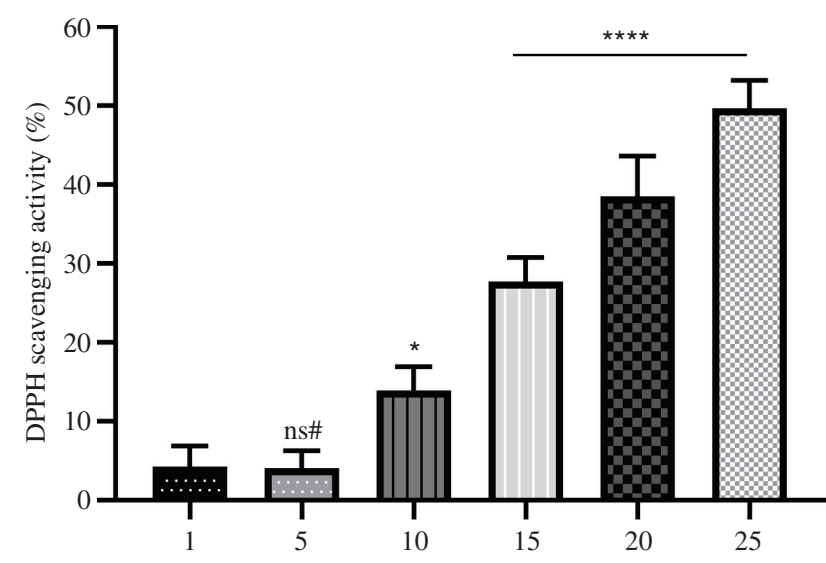

A. horridus extract concentration $(\mathrm{mg} / \mathrm{mL})$

Figure 1: DPPH radical scavenging activity of the different concentrations of methanolic extract of $A$. horridus. Data results were expressed as \% radical scavenging activity relative to $100 \%$ radical scavenging activity of gallic acid as a reference. Values were expressed as the mean \pm standard deviation $(n=3)$. Statistical results were given as ( $n$ s\#, not significant; $\left.p<0.5^{\star}, p<0.0001^{\star \star \star \star}\right)$. 
$\mathrm{mL})$ and expressed in $\mu \mathrm{g}$ quercetin equivalents $(\mathrm{QE}) / \mathrm{mg}$ extract (data was not shown). Our results showed that flavonoid content of $A$. horridus was $51.23 \mu \mathrm{g} / \mathrm{mL}$ at $5 \mathrm{mg} / \mathrm{mL}$ compared to $1 \mathrm{mg} / \mathrm{mL}$ concentration of extract (ns\#). Total flavonoid content of 10, 15, 20, and $25 \mathrm{mg} / \mathrm{mL}$ extracts was determined as 115.19, 161.37, 200.08 and $266.26 \mu \mathrm{g} /$ $\mathrm{mL}$, respectively compared to $1 \mathrm{mg} / \mathrm{mL}$ concentration of extract $(\mathrm{p}<0.0001)$ (Figure 2).

Determination of total phenolic content (TPC) of A. horridus extracts with respect to standard calibration curve of gallic acid was done using Folin-Ciocalteu reagent. The standard calibration curve was obtained from different concentrations of gallic acid $(0-200 \mathrm{mg} /$ $\mathrm{mL}$ ) (data was not shown). The highest TPC of the extract was found as 169.713 ( $\mu \mathrm{g} \mathrm{GAE}) / \mathrm{mg}$ at $20 \mathrm{mg} / \mathrm{mL}$ concentration. At the lowest concentration of $5 \mathrm{mg} / \mathrm{mL}$, TPC was found as 42.61 ( $\mu \mathrm{g} \mathrm{GAE}) / \mathrm{mg}$ and it was demonstrated that there is no statically significant difference between the $\mathrm{TPC}$ of $5 \mathrm{mg} / \mathrm{mL}$ and $10 \mathrm{mg} / \mathrm{mL}$ ( $\mathrm{p}>0.05$ ). However, TPC of the higher extract concentrations at 15,20 and $25 \mathrm{mg} / \mathrm{mL}$ was determined as 140.683, 169.713 and 167.613 ( $\mu \mathrm{g} \mathrm{GAE}$ )/ mg extract, respectively $(\mathrm{p}<0.01)$ (Figure 3$)$.

In the ferric ion reducing antioxidant potential (FRAP) assay, the reducing power capability of extract concentrations between 1 and $25 \mathrm{mg} / \mathrm{mL}$ were illustrated using standard calibration curve of iron sulfate $\left(\mathrm{FeSO}_{4}\right)$ (Figure 4). For the FRAP assay, varying iron sulfate $\left(\mathrm{FeSO}_{4}\right)$ concentrations (200-1000 $\mu \mathrm{g} / \mathrm{mL}$ ) were used as a calibration curve (data was not shown). Reducing power capability of the extract was found to be 0.04, 0.09, 0.36, 0.86, 1.2 and $1.27\left(\mu \mathrm{FeSO}_{4}\right) / \mathrm{mg}$ FRAP values for 1, 5, $10(\mathrm{p}<0.05)$,

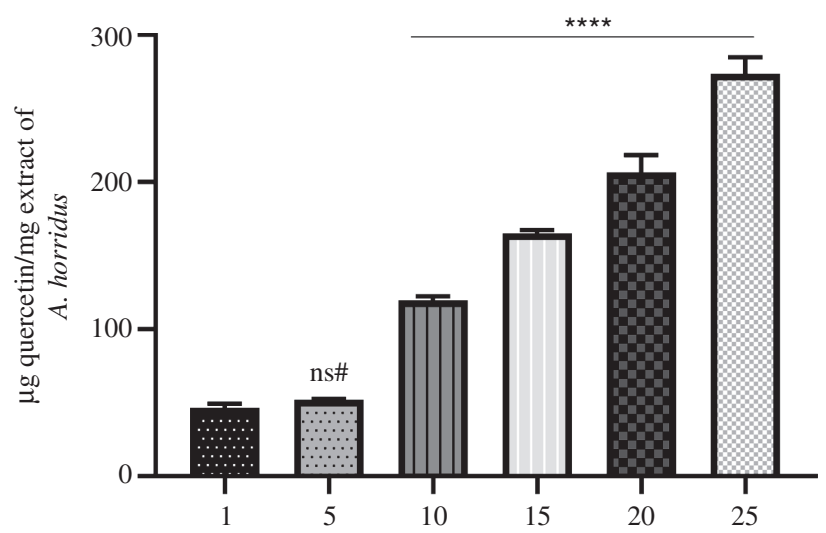

A. horridus extract concentration $(\mathrm{mg} / \mathrm{mL})$

Figure 2: Bar chart representation of total flavonoid content of methanolic extract of $A$. horridus.

Graph shows the total phenolic content expressed as $\mu$ g quercetin/ $\mathrm{mg}$ of extract. Values were expressed as the mean \pm standard deviation $(n=3)$. Results were given as (ns\#, not significant; $\left.\mathrm{p}<0.0001^{\star \star \star \star}\right)$.

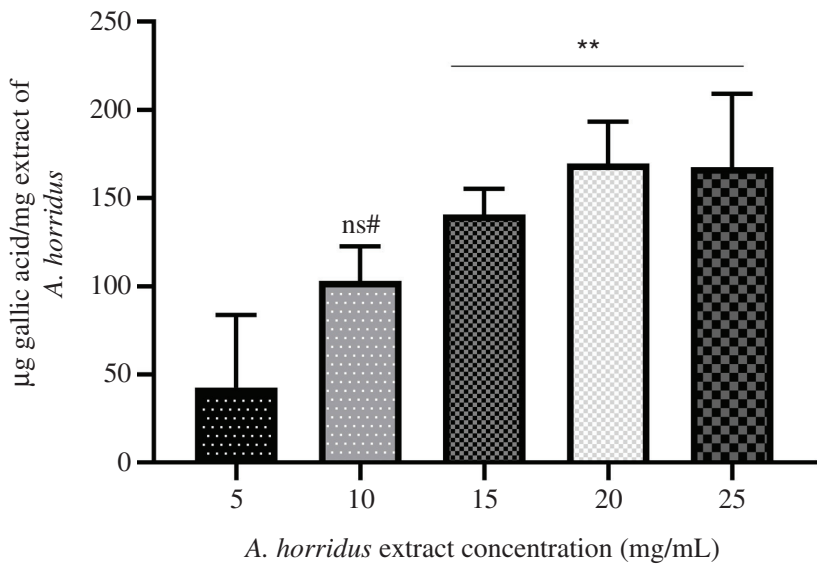

Figure 3: Total phenolic content of $A$. horridus extract. Graph shows the total phenolic content expressed as $\mu \mathrm{g} \mathrm{GAE} / \mathrm{mg}$ of extract. Values are expressed as the mean standard deviation $(n=3)$. Results were given as ( $n$ s\#, not significant; $\left.p<0.01^{\star \star}\right)$.

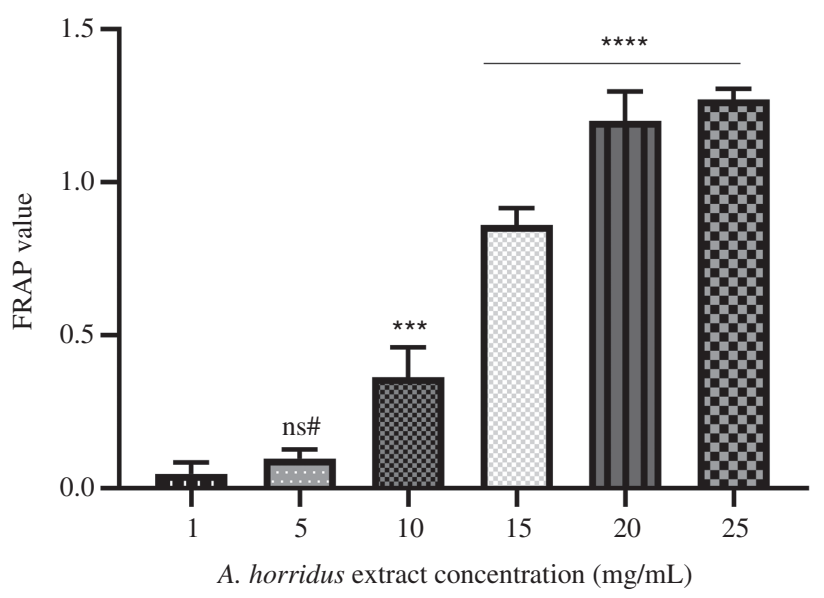

Figure 4: Ferric reducing antioxidant power assay of $A$. horridus extract.

Values were expressed as the mean \pm standard deviation $(n=3)$. Results were given as ( $n$ s\#, not significant; $p<0.001^{\star \star \star}$, $\left.\mathrm{p}<0.0001^{\star \star \star \star}\right)$.

$15(\mathrm{p}<0.0001), 20(\mathrm{p}<0.0001)$ and $25 \mathrm{mg} / \mathrm{mL}(\mathrm{p}<0.0001)$ concentrations of extract, respectively. Statistical evaluations showed that although there was no significant difference $(p<0.05)$ between the concentrations of $5 \mathrm{mg} / \mathrm{mL}$ and $1 \mathrm{mg} / \mathrm{mL}$ extracts, FRAP values for the rest of the concentrations were considered as statistically significant.

\section{Effect of $A$. horridus on in vitro anti- inflammatory activity}

The protein denaturation assay was performed to determine the in vitro anti-inflammatory activity and 
Table 1: Effect at increased concentrations of $A$. horridus and diclofenac sodium against protein denaturation.

\begin{tabular}{lr}
\hline Concentration $(\mathrm{mg} / \mathrm{mL})$ & \% Inhibition of denaturation of BSA \\
\hline 1 & $0.28 \pm 0.08$ \\
5 & $2.72 \pm 0.34$ \\
10 & $9.47 \pm 0.43$ \\
15 & $16.33 \pm 0.61$ \\
20 & $22.67 \pm 0.61$ \\
25 & $29.42 \pm 0.34$ \\
\hline
\end{tabular}

concentration-dependent inhibition of protein-denaturation activity was observed for A. horridus. For proteindenaturation assay, diclofenac sodium was used as a positive control from 100 to $1000 \mu \mathrm{g} / \mathrm{mL}$ concentrations to represent the percentage inhibition of protein denaturation activity ranging between $32.95 \%$ and $83.53 \%$, respectively (data was not shown). As shown in Table 1, percent inhibitions attained by varying extract concentrations exhibited less activity compared to the standard agent and the maximum percent inhibition was observed by the highest extract concentration $(25 \mathrm{mg} / \mathrm{mL})$ as $29.42 \pm 0.34$.

\section{Anti-cancer effect of $A$. horridus on HepG2 and B-CPAP cells}

The MTT assay was performed to evaluate the effects of A. horridus extract on HepG2 and B-CPAP cell proliferation. As shown in Figure 5A, treatment with $1(\mathrm{p}<0.001)$, $5,10,20,50$, and $100 \mu \mathrm{g} / \mathrm{mL}(\mathrm{p}<0.001)$ concentrations of $A$. horridus extract for $24 \mathrm{~h}$, caused a significant reduction in the HepG2 cell viability to $88.76 \%, 75.72 \%, 69.5 \%$, $62.23 \%, 55.31 \%$ and $44.64 \%$, respectively. As shown in Figure 5B, treatment with $10(\mathrm{p}<0.05), 20,50,70,100,150$, 200 and $300 \mu \mathrm{g} / \mathrm{mL}(\mathrm{p}<0.001)$ concentrations of $A$. horridus extract for $24 \mathrm{~h}$ decreased the B-CPAP cell viability to $82.24 \%, 68.74 \%, 62.80 \%, 58.55 \%, 54.03 \%, 44.57 \%, 20 \%$ and $5.69 \%$, respectively. The IC $_{50}$ values of $A$. horridus on HepG2 and B-CPAP cells were $63.24 \mu \mathrm{g} / \mathrm{mL}$ and $101.24 \mu \mathrm{g} /$ $\mathrm{mL}$ after $24 \mathrm{~h}$, respectively.

\section{Discussion}

The aim of the present study was to evaluate the in vitro antioxidant, anti-inflammatory and anti-cancer activities of methanol extract of $A$. horridus on both HepG2 and B-CPAP cancer cells. Extracts derived from nature origin possess phenolic compounds, such as flavonoids, coumarins, phenolic acids. These antioxidant compounds
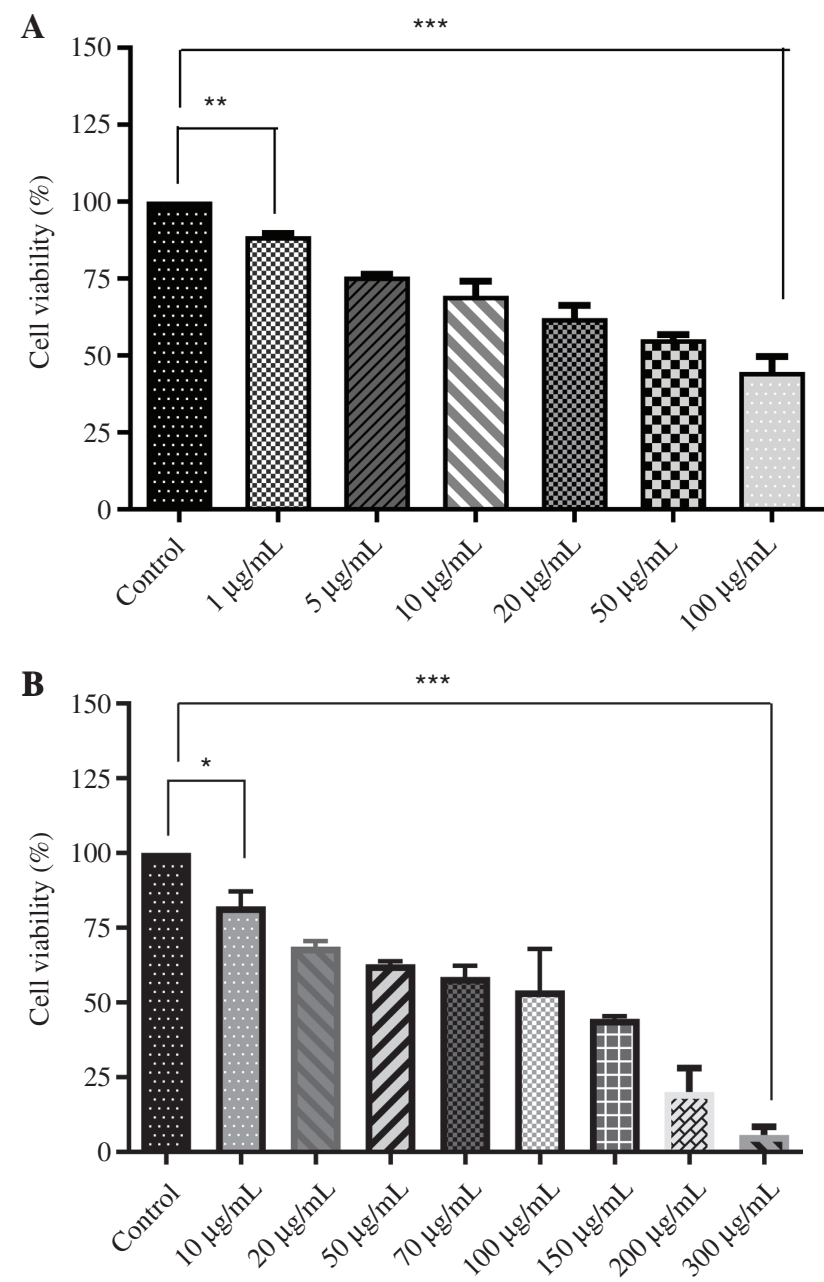

Figure 5: Effects of $A$. horridus on HepG2 and B-CPAP cell viability. Cells were treated with indicated concentrations of the extract on HepG2 (Figure 5A) and B-CPAP (Figure 5B) cancer cells for $24 \mathrm{~h}$. Values were expressed as the mean \pm standard deviation $(n=3)$. Results were given as $\left(p<0.05^{\star}, p<0.01^{\star \star}, p<0.001^{\star \star \star}\right)$.

have anti-inflammatory, anti-cancer, anti-mutagenic, anti-bacterial and apoptotic effects of phenolic compounds [18]. In this study, four different antioxidant methods (DPPH, TPC, TFC and FRAP) were used to determine the antioxidant activity of $A$. horridus. Based on the results of antioxidant assays, it was found that $A$. horri$d u s$ has potential antioxidant capability. Apart from antioxidant tests, anti-inflammatory activity of $A$. horridus extract was analysed via the inhibition studies on albumin degradation.

This study is the first report which focuses on antiinflammatory response of $A$. horridus against denaturation of proteins. In a previous study, $\%$ inhibition of protein denaturation of rhizophora mucronata leaves was observed as $33 \%$, at $100 \mathrm{mg} / \mathrm{mL}$ extract concentration compared to the standard agent, diclofenac sodium [19]. 
This signifies the importance of $29 \%$ inhibition of protein denaturation achieved by $25 \mathrm{mg} / \mathrm{mL}$ A. horridus extract concentration in our study.

Phenolic compounds such as flavonoids have long been reported as chemopreventive agents in cancer treatment [20-22]. Quercetin is a major flavonoid which has an anti-cancer effect against prostate and breast cancers [23]. Gliricidin7-O-hexoside and Quercetin 7-O-rutinoside are known as flavonoids and they have anticancer effect on human hepatoma HepG2 and human carcinoma HeLa cells [24].

The effect of quercetin concentration on the B-CPAP cells proliferation was previously studied and our previous results showed that specifically $50 \mu \mathrm{M}$ and $75 \mu \mathrm{M}$ quercetin concentrations were desired to inhibit the B-CPAP cells proliferation [25]. In our current study, anti-proliferative effect of $A$. horridus on B-CPAP cells was observed and it was found that $A$. horridus extract with $101.24 \mu \mathrm{g} / \mathrm{mL}$ is required to reduce the B-CPAP cell proliferation by half. Based on the vast amount of cytotoxicity and anticancer studies, it has been confirmed that Asparagus species can be used as natural anticancer agent against various types of cancer [6, 11, 26-31]. In the light of literature sources and our studies, it is concluded that methanol extract of A. horridus could be a potential anticancer agent for both liver and thyroid cancer treatments.

Conflict of interest statement: Authors have no conflict of interest regarding this study.

\section{References}

1. Khan IA, Abourashed EA. Leung's encyclopedia of common natural ingredients used in food, drugs, and cosmetics. New Jersey: John Wiley \& Sons, Inc., Publication, 2009:52-3.

2. Shao Y, Poobrasert O, Kennelly EJ, Chin CK, Ho CT, Huang MT, et al. Steroidal saponins from asparagus officinalis and their cytotoxic activity. Planta Med 1997;63:258-62.

3. Adouni K, Chahdoura H, Mosbah H, Santos-Buelga C, GonzálezParamás AM, Ciudad-Mulero M, et al. Revalorization of wild Asparagus stipularis Forssk. as a traditional vegetable with nutritional and functional properties. Food Funct 2018;9:1578-86.

4. Joshi G, Rawat M, Bisht V, Negi J, Singh P. Chemical constituents of Asparagus. Pharmacogn Rev 2010;4:215.

5. Urbani M, Becca G, Ledda G. Notes on systematics and chorology of Asparagus L. (Asparagaceae) in Sardinia (Italy). Bocconea 2007;21:267-72.

6. Huang X-F, Lin Y-Y, Kong L-Y. Steroids from the roots of asparagus officinalis and their cytotoxic activity. J Integr Plant Biol 2008;50:717-22.

7. Cheng W, Cheng Z, Xing D, Zhang M. Asparagus polysaccharide suppresses the migration, invasion, and angiogenesis of hepatocellular carcinoma cells partly by targeting the HIF-1 $\alpha$ /VEGF signalling pathway in vitro. Evidence-Based Complement Altern Med 2019;2019:1-10.

8. Park M, Sook Cheon M, Hwan Kim S, Chun JM, Lee AY, Cheol Moon B, et al. Anticancer activity of asparagus cochinchinensis extract and fractions in HepG2 cells. J Korean Soc Appl Biol Chem 2011;54:188-93.

9. Nwafor PA, Okwuasaba FK. Anti-nociceptive and antiinflammatory effects of methanolic extract of Asparagus pubescens root in rodents. J Ethnopharmacol 2003;84:125-9.

10. Hossain MI, Sharmin FA, Akhter S, Bhuiyan MA, Shahriar M. Investigation of cytotoxicity and in-vitro antioxidant activity of Asparagus racemosus root extract. Int Curr Pharm J 2012;1:250-7.

11. Di Maro A, Pacifico S, Fiorentino A, Galasso S, Gallicchio M, Guida V, et al. Raviscanina wild asparagus (Asparagus acutifolius L.): A nutritionally valuable crop with antioxidant and antiproliferative properties. Food Res Int 2013;53:180-8.

12. Alara OR, Abdurahman NH, Olalere OA. Ethanolic extraction of bioactive compounds from Vernonia amygdalina leaf using response surface methodology as an optimization tool. J Food Meas Charact 2018;12:1107-22.

13. Kim D-O, Jeong SW, Lee CY. Antioxidant capacity of phenolic phytochemicals from various cultivars of plums. Food Chem 2003;81:321-6.

14. Alara OR, Abdurahman NH, Olalere OA. Optimization of microwave-assisted extraction of flavonoids and antioxidants from Vernonia amygdalina leaf using response surface methodology. Food Bioprod Process 2018;107:36-48.

15. Vijayalakshmi M, Ruckmani K. Ferric reducing anti-oxidant power assay in plant extract. Bangladesh J Pharmacol 2016;11:570.

16. Williams LA, O'Connar A, Latore L, Dennis O, Ringer S, Whittaker $J A$, et al. The in vitro anti-denaturation effects induced by natural products and non-steroidal compounds in heat treated (immunogenic) bovine serum albumin is proposed as a screening assay for the detection of anti-inflammatory compounds, without the use of animals, in the early stages of the drug discovery process. West Indian Med J 2008;57:327-31.

17. van der Heijden AG, Jansen CF, Verhaegh G, O'Donnell MA, Schalken JA, Witjes JA. The effect of hyperthermia on mitomycin$C$ induced cytotoxicity in four human bladder cancer cell lines. Eur Urol 2004;46:670-4.

18. Fereidoon S, Judong Y. Bioactivities of phenolics by focusing on suppression of chronic diseases: a review. Int J Mol Sci. 2018;19:1573.

19. Kumari CS, Yasmin N, Raffiq Hussain M, Babuselvam M. In vitro anti-inflammatory and anti-arthritic property of Rhızopora mucronata leaves. IJPRS 2015;6:482-5.

20. Ahmed SI, Hayat MQ, Tahir M, Mansoor Q, Ismail M, Keck K, et al. Pharmacologically active flavonoids from the anticancer, antioxidant and antimicrobial extracts of Cassia angustifolia Vahl. BMC Complement. Altern Med 2016;16:460.

21. Mishra A, Sharma AK, Kumar S, Saxena AK, Pandey AK. Bauhinia variegata leaf extracts exhibit considerable antibacterial, antioxidant, and anticancer activities. Bio Med Res Int 2013:Article ID: 915436.

22. Brusselmans K, De Schrijver E, Heyns W, Verhoeven G, Swinnen JV. Epigallocatechin-3-gallate is a potent natural inhibitor of fatty acid synthase in intact cells and selectively induces apoptosis in prostate cancer cells. Int J Cancer 2003;106:856-62. 
23. Kumar S, Pandey AK. Chemistry and biological activities of flavonoids: an overview. Sci World J 2013;16:162750.

24. Jarial R, Thakur S, Sakinah M, Zularisam AW, Sharad A, Kanwar SS, et al. Potent anticancer, antioxidant and antibacterial activities of isolated flavonoids from Asplenium nidus. J King Saud Univ-Sci 2018;30:185-92.

25. Mutlu Altundağ E, Kasaci T, Yilmaz AM, Karademir B, Koçtürk S, Taga Y, et al. Quercetin-induced cell death in human papillary thyroid cancer (B-CPAP) cells. J Thyroid Res 2016;2016:Article ID: 9843675.

26. Ji Y, Ji C, Yue L, Xu H. Saponins isolated from Asparagus induce apoptosis in human hepatoma cell line HepG2 through a mitochondrial-mediated pathway. Curr Oncol 2012;19:eS1-9.

27. Liu W, Huang X-F, Qi Q, Dai QS, Yang L, Nie FF, et al. Asparanin A induces $\mathrm{G} 2 / \mathrm{M}$ cell cycle arrest and apoptosis in human hepatocellular carcinoma HepG2 cells. Biochem Biophys Res Commun 2009;381:700-5.
28. Liu W, Ning R, Chen R-N, Huang XF, Dai QS, Hu JH, et al. Aspafilioside $B$ induces $G 2 / M$ cell cycle arrest and apoptosis by up-regulating $\mathrm{H}$-Ras and $\mathrm{N}$-Ras via ERK and p38 MAPK signaling pathways in human hepatoma HepG2 cells. Mol Carcinog 2016;55:440-57.

29. Wang J, Liu Y, Zhao J, Zhang W, Pang X. Saponins extracted from by-product of Asparagus officinalis L. suppress tumour cell migration and invasion through targeting Rho GTPase signalling pathway. J Sci Food Agric 2013;93:1492-8.

30. Xiang J, Xiang Y, Lin S, Xin D, Liu X, Weng L, et al. Anticancer effects of deproteinized asparagus polysaccharide on hepatocellular carcinoma in vitro and in vivo. Tumor Biol 2014;35:3517-24.

31. Zhang W, He W, Shi X, Li X, Wang Y, Hu M, et al. An Asparagus polysaccharide fraction inhibits MDSCs by inducing apoptosis through toll-like receptor 4. Phyther Res 2018;32:1297-303. 